Prepared in cooperation with Miami-Dade County

\title{
Map of the Approximate Inland Extent of Saltwater at the Base of the Biscayne Aquifer in Miami-Dade County, Florida, 2018
}

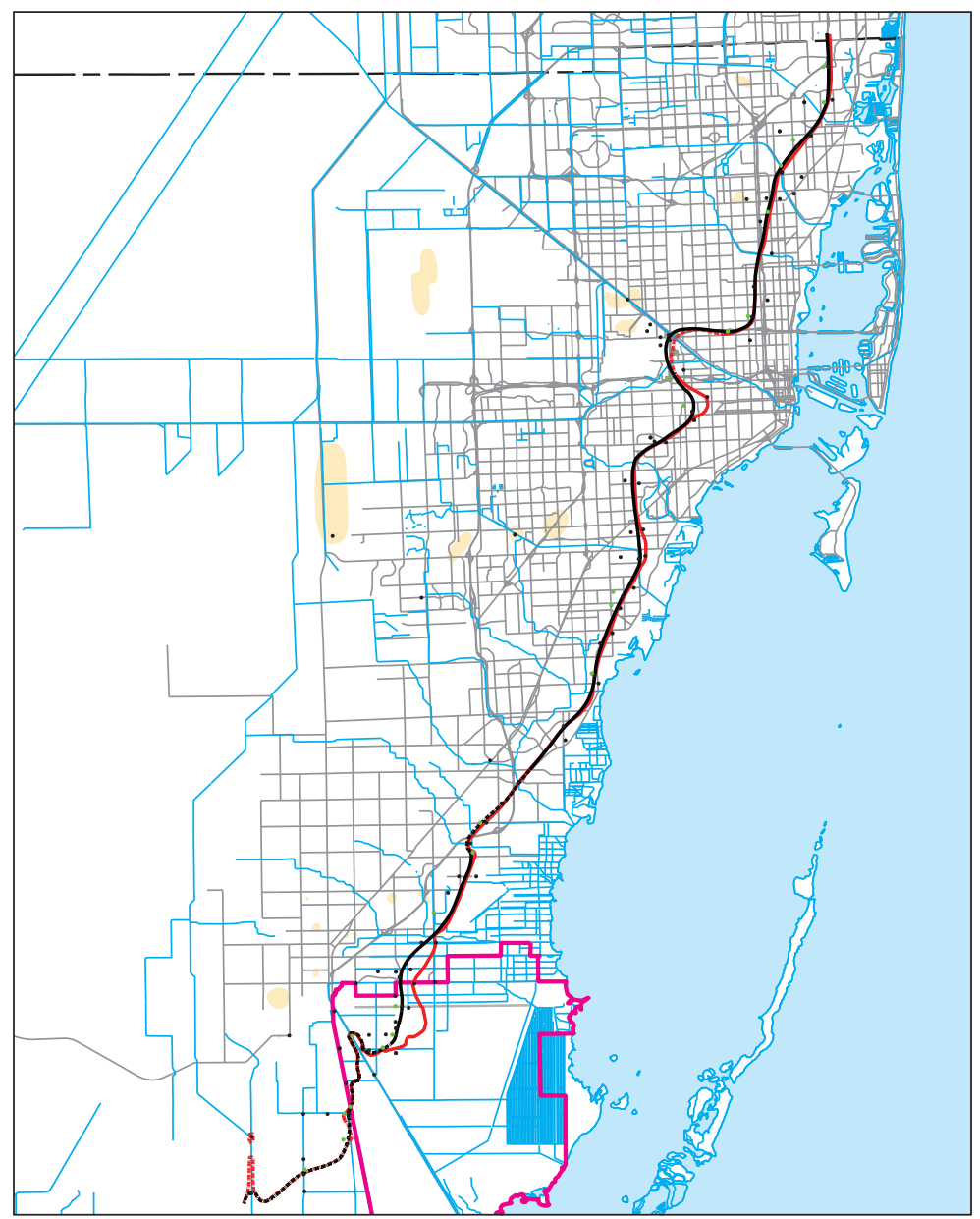

Pamphlet to accompany

Scientific Investigations Map 3438 
Cover. Map showing the approximate extent of saltwater at the base of the Biscayne aquifer in Miami-Dade County, Florida, 2011 and 2018. See https://doi.org/10.3133/sim3438 for map sheet. 


\section{Map of the Approximate Inland Extent of Saltwater at the Base of the Biscayne Aquifer in Miami-Dade County, Florida, 2018}

By Scott T. Prinos

Prepared in cooperation with Miami-Dade County

Pamphlet to accompany

Scientific Investigations Map 3438 


\title{
U.S. Department of the Interior DAVID BERNHARDT, Secretary
}

\author{
U.S. Geological Survey \\ James F. Reilly II, Director
}

U.S. Geological Survey, Reston, Virginia: 2019

For more information on the USGS - the Federal source for science about the Earth, its natural and living resources, natural hazards, and the environment-visit https://www.usgs.gov or call 1-888-ASK-USGS.

For an overview of USGS information products, including maps, imagery, and publications, visit https://store.usgs.gov.

Any use of trade, firm, or product names is for descriptive purposes only and does not imply endorsement by the U.S. Government.

Although this information product, for the most part, is in the public domain, it also may contain copyrighted materials as noted in the text. Permission to reproduce copyrighted items must be secured from the copyright owner.

Suggested citation:

Prinos, S.T., 2019, Map of the approximate inland extent of saltwater at the base of the Biscayne aquifer in Miami-Dade County, Florida, 2018: U.S. Geological Survey Scientific Investigations Map 3438, 10-p. pamphlet, 1 sheet, https://doi.org/10.3133/sim3438.

ISSN 2329-132X (online) 


\section{Acknowledgments}

The author would like to acknowledge the organizations that provided data for this study: Florida Department of Environmental Protection, Florida Keys Aqueduct Authority, Florida Power \& Light Company, MacVicar Consulting, Inc., Miami-Dade County Department of Regulatory and Economic Resources, and the South Florida Water Management District, as well as specific individuals who provided the data from these organizations: Rick Copeland, Maria Idia Macfarlane, Sharon Ewe, Shelli Johnson, Kellie Madison, Thomas MacVicar, Sara Mechtensimer, Liz Miller, Jolynn Reynolds, and Dongwei Zhu. The author would also like to acknowledge the work of the following U.S. Geological Survey personnel who collected most of the data used for this effort: Adrian Castillo, Jesse Greathouse, Adam Hines, Taylor Kall, Roberto Ravelo, Kevin Reyes, Lee Massey, Delaney McCullough, and Robert Valderrama. Without the data provided by these people and organizations, the map in this report could not have been created. 



\section{Contents}

Acknowledgments …….................................................................................................................

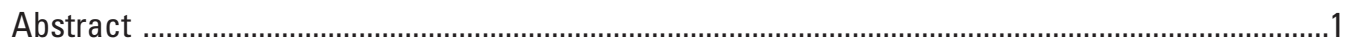

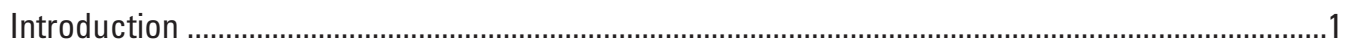

Mapping the Approximate Inland Extent of the Saltwater Interface ..................................................

Approximating the Rate of Movement of the Saltwater Interface ...................................................

Estimating Chloride Concentrations and Dates of Arrival .........................................................

Estimated Movement Rates of the Saltwater Interface ...........................................................

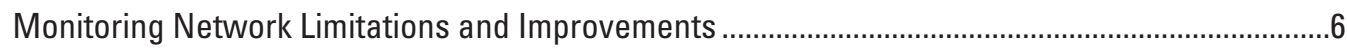

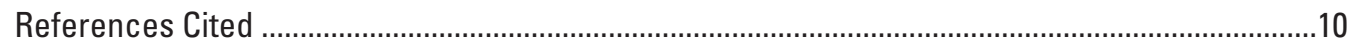

\section{Figures}

1. Graph showing linear regression of chloride concentration and specific conductance in the Model Land Area, Miami-Dade County, Florida ..................................

2. Graph showing regression of estimated chloride concentration in well $\mathrm{ACl}-\mathrm{MW}-05-\mathrm{FS}$ and the dates of the specific conductance measurements used to estimate these chloride concentrations, Miami-Dade County, Florida.

\section{Tables}

1. U.S. Geological Survey monitoring wells from which data collected during October $26,1999-J u l y ~ 23,2018$, were used to compute a linear regression of chloride concentration and specific conductance in the Model Land Area, Miami-Dade County, Florida...

2. Specific conductance values used in regression of estimated chloride concentration from well ACI-MW-05-FS at a depth of 27.4 meters, Miami-Dade County, Florida.

3. Saltwater intrusion monitoring wells that have open intervals longer than 4 meters in Miami-Dade County, Florida ..................................................................................

4. Proposed locations and reasons for new monitoring wells in Miami-Dade County, Florida

\section{Sheet}

[Available from https://doi.org/10.3133/sim3438]

1. Map of the approximate inland extent of saltwater at the base of the Biscayne aquifer in Miami-Dade County, Florida, 2018 


\section{Conversion Factors}

International System of Units to U.S. customary units

\begin{tabular}{|c|c|c|}
\hline Multiply & By & To obtain \\
\hline \multicolumn{3}{|c|}{ Length } \\
\hline meter $(\mathrm{m})$ & 3.281 & foot $(\mathrm{ft})$ \\
\hline kilometer $(\mathrm{km})$ & 0.6214 & mile (mi) \\
\hline \multicolumn{3}{|c|}{ Area } \\
\hline square kilometer $\left(\mathrm{km}^{2}\right)$ & 247.1 & acre \\
\hline square kilometer $\left(\mathrm{km}^{2}\right)$ & 0.3861 & square mile $\left(\mathrm{mi}^{2}\right)$ \\
\hline \multicolumn{3}{|c|}{ Volume } \\
\hline liter $(\mathrm{L})$ & 0.2642 & gallon (gal) \\
\hline liter $(\mathrm{L})$ & 61.02 & cubic inch $\left(\right.$ in $\left.^{3}\right)$ \\
\hline \multicolumn{3}{|c|}{ Flow rate } \\
\hline meter per year (m/yr) & 3.281 & foot per year (ft/yr) \\
\hline liter per minute (L/min) & 0.2642 & gallon per minute (gal/min) \\
\hline \multicolumn{3}{|c|}{ Mass } \\
\hline gram $(\mathrm{g})$ & 0.03527 & ounce, avoirdupois (oz) \\
\hline kilogram (kg) & 2.205 & pound avoirdupois (lb) \\
\hline \multicolumn{3}{|c|}{ Electrical conductivity } \\
\hline siemens per meter $(\mathrm{S} / \mathrm{m})$ & 10,000 & $\begin{array}{l}\text { microsiemens per centimeter } \\
\qquad(\mu \mathrm{S} / \mathrm{cm})\end{array}$ \\
\hline
\end{tabular}

Electrical conductivity $\sigma$ in microsiemens per centimeter $[\mu \mathrm{S} / \mathrm{cm}]$ can be converted to electrical resistivity $\rho$ in ohm-meters [ohm m] as follows: $\rho=10,000 / \sigma$.

Temperature in degrees Celsius $\left({ }^{\circ} \mathrm{C}\right)$ may be converted to degrees Fahrenheit $\left({ }^{\circ} \mathrm{F}\right)$ as follows:

${ }^{\circ} \mathrm{F}=\left(1.8 \times{ }^{\circ} \mathrm{C}\right)+32$

\section{Datum}

Horizontal coordinate information is referenced to the North American Datum of 1983 (NAD 83).

\section{Supplemental Information}

Specific conductance is given in microsiemens per centimeter at 25 degrees Celsius ( $\mu \mathrm{S} / \mathrm{cm}$ at $\left.25^{\circ} \mathrm{C}\right)$.

Concentrations of chemical constituents in water are given in milligrams per liter (mg/L). 


\section{Abbreviations}

FDEP Florida Department of Environmental Protection

SFWMD South Florida Water Management District

TDS total dissolved solids

TSEMIL time-series electromagnetic-induction log (dataset)

USGS U.S. Geological Survey 



\title{
Map of the Approximate Inland Extent of Saltwater at the Base of the Biscayne Aquifer in Miami-Dade County, Florida, 2018
}

\author{
By Scott T. Prinos
}

\section{Abstract}

The inland extent of saltwater at the base of the Biscayne aquifer in eastern Miami-Dade County, Florida, was mapped in 2011, and it was mapped in the Model Land Area in 2016. The saltwater interface has continued to move inland in some areas and is now near several active well fields. An updated approximation of the inland extent of saltwater has been created by using data collected during March 8-December 13, 2018, from 111 monitoring wells open to the Biscayne aquifer near its base. Chloride concentrations in water samples from the monitoring wells and bulk conductivity from geophysical logs and measurements of the specific conductance of groundwater were used to approximate the position of the isochlor representing a chloride concentration of 1,000 milligrams per liter $(\mathrm{mg} / \mathrm{L})$ at the base of the Biscayne aquifer.

An average rate of saltwater interface movement of about 102 meters per year in the Model Land Area along SW 360 Street was estimated from the approximated dates of arrival of the 250-, 500-, and 1,000-mg/L isochlors at wells TPGW-7L (2013-2014) and ACI-MW-05-FS (2017-2018). This estimate assumes that the interface is traveling in a path parallel to an imaginary line connecting the two monitoring wells.

Of the 111 wells from which data were used, 80 wells have open intervals of $\leq 4$ meters, 20 of the wells have open intervals that range from 4.3 to 39.6 meters, and the lengths of the open intervals could not be determined in 11 wells. Studies have shown that long open intervals might allow water from various depths to mix under ambient or pumped conditions, which in turn could alter the maximum chloride concentration sampled in the well, or it might change the depth at which the maximum specific conductance is measured within a well, relative to its depth in the aquifer. The approximation of the inland extent of the saltwater interface and the estimated rate of movement of the interface are dependent on the quality of existing data. Improved estimates could be obtained by installing uniformly designed monitoring wells in systematic transects extending landward of the advancing saltwater interface. To achieve this goal, Miami-Dade County and some other organizations are routinely adding new monitoring wells with short open intervals and replacing poorly designed or positioned monitoring wells to improve spatial coverage of the network.

\section{Introduction}

Miami-Dade County is a low-lying area in southeastern Florida that has abundant annual precipitation, and very little topographic relief. The county has an area of 4,900 square kilometers $\left(\mathrm{km}^{2}\right)$ (U.S. Census Bureau, 2019). It is bordered by the Atlantic Ocean on the east and Florida Bay on the south. Natural drainage in the county is relatively poor. Prior to development, approximately $3,000 \mathrm{~km}^{2}$ of Miami-Dade County was covered by the freshwater marshes of the Everglades (Prinos and others, 2014). General William S. Harney, who had crossed part of the Everglades during the first Seminole War (1817-1818), described the Everglades as a freshwater lake, 97-145 kilometers $(\mathrm{km})$ in length and 0.8-2 meters $(\mathrm{m})$ deep, interspersed with thousands of islands (Fletcher, 1911). The poor natural drainage necessitated development of an extensive man-made drainage network consisting of numerous drainage canals, levees, and water control structures. Beginning early in the 20th century, canals were dredged into the Everglades to drain the marshland. This drainage ultimately reduced freshwater levels by an estimated $2.9 \mathrm{~m}$ below predrainage conditions near the city of Miami (Prinos and others, 2014).

The county's primary water supply is the Biscayne aquifer. This is a wedge-shaped, highly porous, karstic limestone and sand aquifer that is the uppermost part of the surficial aquifer system in southeast Florida (Fish and Stewart, 1991). The Biscayne aquifer is deepest near the coast and thinner in the western part of the county. The Biscayne aquifer is particularly susceptible to saltwater intrusion because of its proximity to saltwater bodies and because the land-surface altitude for about 70 percent of the county is below $1.8 \mathrm{~m}$ (Prinos and others, 2014). Saltwater intrusion is a concern because it can render the water unpotable in affected parts of the aquifer and desalination is costly. The maximum concentration of chloride allowed in drinking water is 250 milligrams per liter (mg/L; U.S. Environmental Protection Agency, 2017), whereas saltwater-intruded parts of the aquifer commonly have water with chloride concentrations of $1,000 \mathrm{mg} / \mathrm{L}$ or greater. In homogenous coastal aquifers like the Biscayne, if freshwater levels are insufficient to balance 
seawater levels, saltwater from the ocean will intrude the aquifer. This saltwater tends to intrude first along the aquifer's base because saltwater is denser than freshwater. If saltwater intrudes farther inland, it tends to form a wedge-shaped mass that is thickest near the coast and becomes thinner farther inland. The saltwater interface is the part of the aquifer where freshwater from the aquifer mixes with intruding saltwater. In this interface, chloride concentrations generally increase relatively sharply from less than $100 \mathrm{mg} / \mathrm{L}$ to well over $1,000 \mathrm{mg} / \mathrm{L}$.

As freshwater levels declined beginning in the early 20th century, and as saltwater flowed inland up the drainage canals during droughts and extreme storm events, saltwater began intruding the Biscayne aquifer of Miami-Dade County, such that by 2011 approximately $1,200 \mathrm{~km}^{2}$ of the mainland part of the Biscayne aquifer had been intruded by saltwater (Prinos and others, 2014). Saltwater has continued to intrude. The approximate inland extent of saltwater at the base of the Biscayne aquifer in Miami-Dade County was mapped in 2011 (Prinos and others, 2014). In 2016, the approximate inland extent of saltwater intrusion in the southeastern part of Miami-Dade County, which is called the Model Land Area, was mapped (Prinos, 2017a, b). Saltwater is continuing to intrude beneath the Model Land Area and in other areas in the county and is approaching several active well fields; therefore, an updated map showing the approximation of the inland extent of saltwater was needed.

In 2018, the U.S. Geological Survey (USGS), in cooperation with Miami-Dade County, mapped the approximate inland extent of saltwater intrusion in Miami-Dade County and estimated the average rate of movement of the saltwater interface in the Model Land Area. The purpose of this report is to provide a map of the saltwater interface (2018), an estimate of the rate of interface movement, and a description of the methodologies used to arrive at these results. The analyses and estimates are based on available data from existing monitoring wells in Miami-Dade County. Potential improvements to the salinity monitoring network are discussed.

\section{Mapping the Approximate Inland Extent of the Saltwater Interface}

Approximation of the inland extent of the saltwater interface in the Biscayne aquifer required acquisition and compilation of relevant data collected by the following organizations: Florida Department of Environmental Protection (FDEP), Florida Keys Aqueduct Authority, Florida Power \& Light Company, MacVicar Consulting, Inc., Miami-Dade County Department of Regulatory and Economic Resources, and the South Florida Water Management District (SFWMD). Any redundant sample results were reviewed to determine if they would modify the interpreted inland extent of the saltwater interface. None were sufficiently different to alter the final interpretation. Data collected between March 8 and December 13, 2018, from 111 wells that were located close enough to the saltwater interface to be relevant were used to map the inland extent of saltwater. The data from the selected wells are available through a USGS data release (Prinos, 2019). Based on this selection process, none of the data provided by the FDEP and Miami-Dade County Department of Regulatory and Economic Resources were used, and most of the data provided by the SFWMD were not used. The majority (80) of the 111 monitoring wells selected for this analysis have open intervals $\leq 4 \mathrm{~m}$; however, 20 of the 111 wells have open intervals that range from 4.3 to $39.6 \mathrm{~m}$ in length, and the lengths of the open intervals could not be determined in 11 wells.

Data from the selected monitoring wells were entered into a geographic information system for analysis and mapping. Most of these data consisted of chloride concentrations in water samples from wells. MacVicar Consulting, Inc., collects profiles of the specific conductance of water from wells with long open intervals. The chloride concentration in water in these wells was estimated by using a linear regression of chloride concentration and specific conductance of water samples from seven USGS monitoring wells in the Model Land Area as described in the report section "Estimating Chloride Concentrations and Dates of Arrival". Time-series electromagnetic-induction log (TSEMIL) datasets provided additional qualitative insights for mapping, such as detection of any masses of conductive groundwater near the well that cannot be sampled through the open interval of the well and temporal changes in the depth of the top of the saltwater interface (Valderrama, 2018).

For mapping purposes, the approximate inland extent of the saltwater interface in the Biscayne aquifer is represented by the $1,000-\mathrm{mg} / \mathrm{L}$ isochlor at its base. The accuracy and precision of this approximation is best evaluated on a location-by-location basis given the distribution of available monitoring wells. The locations of the monitoring wells and the chloride concentration values are shown on the map (sheet 1 of this publication). The line depicting the approximate inland extent of saltwater is dashed where the monitoring well distribution is insufficient to create a reasonably accurate and precise approximation.

Sampling, analysis, and quality assurance procedures of the organizations collecting salinity data in the study area vary. Much of the data stored by the SFWMD and FDEP were collected by other organizations to fulfill permit requirements. These data have been collected by using a variety of techniques and methods. FDEP provides guidelines for the collection of water-quality samples, which are used by some of the organizations from which data were used for mapping the saltwater interface (FDEP, 2017). Procedures used by the Florida Power \& Light Company for sampling and quality assurance are described in the Turkey Point Quality Assurance Project Plan (Florida Power \& Light Company, 2011). This plan was drafted jointly by the FDEP, the Florida Power \& Light Company, and the SFWMD and was approved by the SFWMD. Florida Keys Aqueduct Authority and MacVicar Consulting, Inc., base their sampling on the guidelines of the 
FDEP. MacVicar Consulting, Inc., follows the manufacturer's recommendations for calibration and measurements for collection of specific conductance profiles.

Procedures used by the USGS in south Florida for chloride concentration and specific conductance water sampling have been streamlined for expediency and efficacy of routine, long-term monitoring. Samples are collected by using small, gasoline powered, centrifugal suction pumps that can pump at rates of up to about 120 liters per minute. To prevent excessive drawdown during sampling, pump rates used for sampling are lower than the maximum pump rate; however, rates are generally higher than those attainable with conventional water sampling pumps and would not be feasible except in aquifers like those in south Florida that have extremely high transmissivities. Three to five well volumes of water are purged prior to sample collection. Purge water is monitored by using a specific conductance meter. Samples are not filtered. Pumps are cleaned daily with Liquinox and water. These procedures have proven to be adequate for detecting the large changes in chloride concentrations that occur as the saltwater interface passes monitoring wells. These procedures are not used for high-resolution water-quality sampling, which is conducted by following the procedures described in the USGS national field manual for the collection of water-quality data (USGS, variously dated).

To ensure the quality of analyzed samples, the USGS laboratory participates in the Branch of Quality Systems Standard Reference Sample Semi-Annual Proficiency Testing Project. Florida Power \& Light Company and MacVicar Consulting, Inc., use laboratories that are certified through the National Environmental Laboratory Accreditation Program. Participation in this accreditation program likely assures that sample analyses are accurate; however, the USGS cannot completely verify this accuracy without reviewing the results of the accreditation testing for each laboratory used.

\section{Approximating the Rate of Movement of the Saltwater Interface}

The 2018 approximation of the inland extent of the saltwater interface at the base of the Biscayne aquifer is, in most areas, farther inland than that which was mapped in 2011 (Prinos and others, 2014). Throughout most of the county, this is a qualitative assessment. Chloride concentrations in water samples from wells to the east of the saltwater interface have generally increased since 2011, thereby indicating inland movement. In many instances, however, no corresponding increases in chloride concentrations have been observed in the wells on the western side of the interface.

Exceptions include:

1. In and near the Model Land Area where the interface has passed well clusters G-3966S and G-3966D and is currently passing wells ACI-MW-05-FS, FKS-14, and G-3999.
2. At wells G-1009B, G-3608, and G-3996 near the Snapper Creek Canal.

3. An area extending about $6 \mathrm{~km}$ from the Miami International Airport and the Miami Canal where samples from well G-1354, which were fresh in 2011, became salty, and where samples from wells G-3977D and G-3603, west of the interface, are indicating increasing chloride concentrations.

4. In northern Miami-Dade County where the interface is passing well G-3978 and the G-3949 well cluster. Although the chloride concentrations in water samples from these wells are not high yet, TSEMIL datasets indicate that the interface is passing these wells.

Aside from qualitative estimations based on differences in the mapped inland extents of saltwater intrusion, rates of travel between specific monitoring wells can be estimated at only a few locations where the saltwater interface passed a monitoring well during its period of record. One place where the rate of movement of the interface can be calculated is in the Model Land Area where wells Sec34-MW-02-FS, TPGW-7L, and ACI-MW-05-FS are in an east-west transect along SW 360 Street.

\section{Estimating Chloride Concentrations and Dates of Arrival}

To estimate chloride concentration from specific conductance, Prinos (2017b) used a relation based on 16,184 water samples collected between November 28, 1940 , and September 26, 2016, from 178 monitoring sites sampled by the USGS in southern Florida. Rather than using that relation, this report uses a linear regression (fig. 1) of the chloride concentration and specific conductance of 249 water samples from 7 monitoring wells sampled by the USGS in the Model Land Area between October 26, 1999, and July 23, 2018, which had chloride concentrations less than $2,000 \mathrm{mg} / \mathrm{L}$ (fig. 1; table 1). The reasons for this change in the method of estimation are to (1) ensure that the samples used are most representative of water in the Model Land Area where the regressions are necessary to compute interface movement rate; (2) better compensate for the effect of deviations from linearity at lower salinities by reducing the range of data in the regression; (3) improve the precision of the estimate by removing variation that could be caused by differences in the geochemistry of other aquifers and regions; and (4) narrow the regression to samples that have chloride concentrations $\leq 2,000 \mathrm{mg} / \mathrm{L}$ because the wells being monitored by MacVicar Consulting, Inc., generally yielded samples with specific conductance values less than 4,000 microsiemens per centimeter at 25 degrees Celsius. This narrowing of the input data for the regression analysis resulted in an improved coefficient of determination $\left(\mathrm{R}^{2}\right)$ for the linear regression (fig. 1). All of the sample results used are available through the USGS National Water Information System 


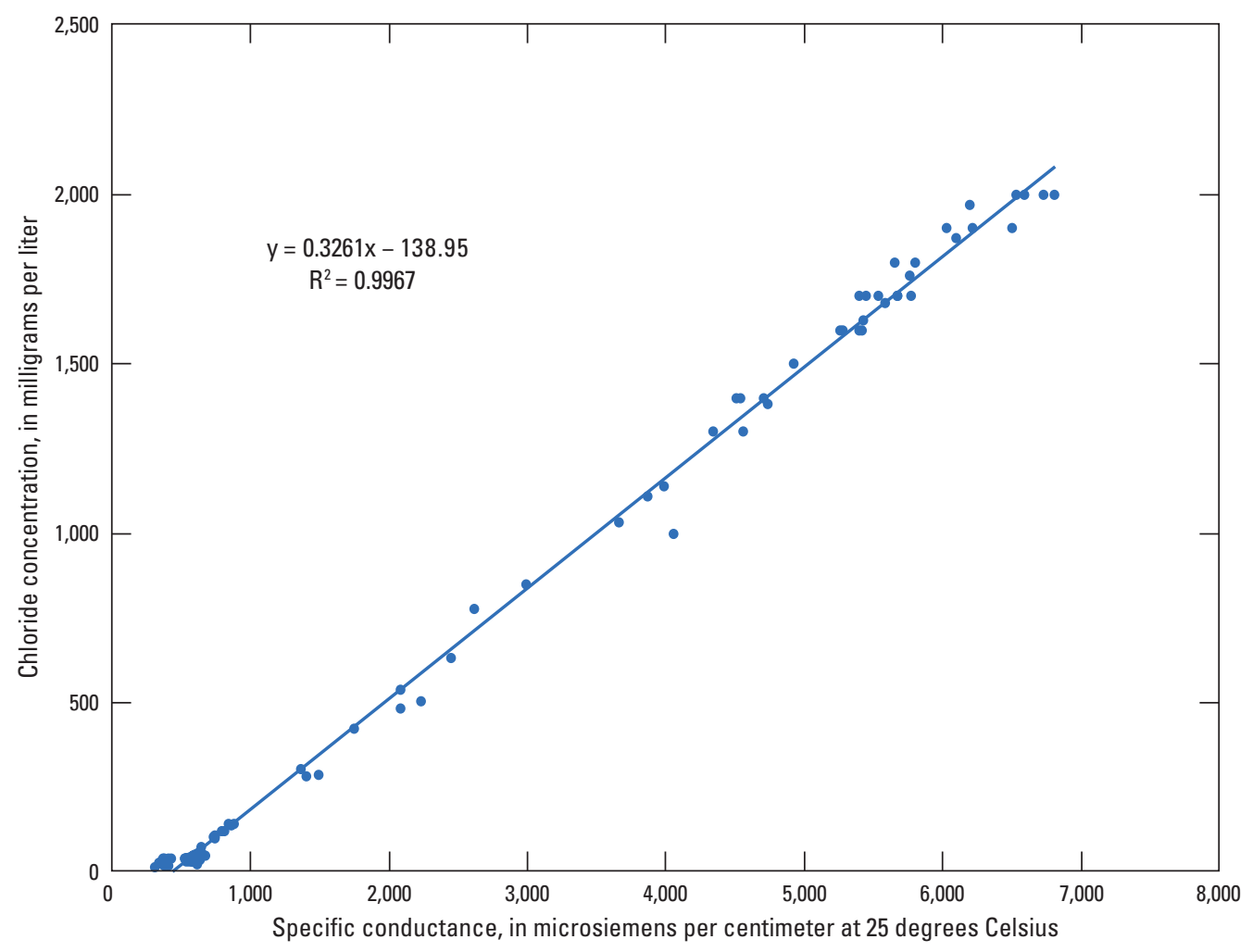

Figure 1. Linear regression of chloride concentration and specific conductance in the Model Land Area, Miami-Dade County, Florida.

Table 1. U.S. Geological Survey monitoring wells from which data collected during October 26, 1999-July 23, 2018, were used to compute a linear regression of chloride concentration and specific conductance in the Model Land Area, Miami-Dade County, Florida.

[USGS, U.S. Geological Survey]

\begin{tabular}{cc}
\hline USGS site identifier & $\begin{array}{c}\text { Site name } \\
\text { (see sheet 1) }\end{array}$ \\
\hline 252814080244101 & G-3698 \\
252718080264901 & G-3900 \\
252431080261002 & G-3946S \\
252719080253601 & G-3966D \\
252714080260901 & G-3976 \\
252626080261001 & G-3998 \\
252506080261001 & G-3999 \\
\hline
\end{tabular}

website (USGS, 2019b). The resulting relation of chloride concentration and specific conductance is expressed as

$$
c c=0.3261 s c-138.95
$$

where

$$
\begin{aligned}
& c c \quad \text { is the chloride concentration in milligrams per } \\
& \text { liter and } \\
& s c \quad \text { is the specific conductance in microsiemens } \\
& \text { per centimeter. }
\end{aligned}
$$

A regression of the chloride concentrations estimated from specific conductance measurements from a depth of $27.4 \mathrm{~m}$ in well ACI-MW-05-FS and the dates of these measurements were used to estimate the dates of arrival of the 250-, 500-, and 1,000-mg/L isochlors at this well (table 2; fig. 2). The resulting relation is expressed as

$$
d t=41,373 c c^{0.007}
$$

where

$$
\begin{aligned}
& d t \quad \text { is date of the measurement (expressed in } \\
& \text { Excel as days since January 0, 1900), and } \\
& c c \quad \text { is estimated chloride concentration in } \\
& \text { milligrams per liter. }
\end{aligned}
$$

Chloride concentrations in well ACI-MW-05-FS were estimated by using specific conductance measurements 
Table 2. Specific conductance values used in regression of estimated chloride concentration from well ACI-MW-05-FS at a depth of 27.4 meters, Miami-Dade County, Florida.

$[\mathrm{m}$, meter; $\mathrm{mg} / \mathrm{L}$, milligrams per liter; $\mu \mathrm{S} / \mathrm{cm}$, microsiemens per centimeter at 25 degrees Celsius]

\begin{tabular}{ccc}
\hline $\begin{array}{c}\text { Date of } \\
\text { measurement }\end{array}$ & $\begin{array}{c}\text { Specific } \\
\text { conductance } \\
\text { ( } \mathbf{S} / \mathbf{c m} \text { ) measured at } \\
\text { a depth of 27.4 } \mathbf{~} \text { in } \\
\text { well ACI-MW05-FS }\end{array}$ & $\begin{array}{c}\text { Estimated chloride } \\
\text { concentration } \\
\text { (mg/L) }\end{array}$ \\
\hline $1 / 31 / 2018$ & 1,612 & 387 \\
$4 / 11 / 2018$ & 1,771 & 439 \\
$6 / 11 / 2018$ & 2,182 & 573 \\
$7 / 12 / 2018$ & 2,266 & 600 \\
$8 / 29 / 2018$ & 2,777 & 767 \\
$12 / 13 / 2018$ & 3,573 & 1,026 \\
\hline
\end{tabular}

from a depth of $27.4 \mathrm{~m}$ in equation 1. Dates of arrival of the 250-, 500-, and 1,000-mg/L isochlors at this well were estimated by using equation 2 . Linear interpolations of chloride concentrations and sample dates were used to determine when these isochlors arrived at well TPGW-7L as described in Prinos (2017b). In addition to the information provided by Prinos (2017b), the date of arrival of the $500-\mathrm{mg} / \mathrm{L}$ isochlor at well TPGW-7L was interpolated from the data cited in that report. The estimated average rate of movement of the interface between wells TPGW-7L and well ACI-MW-05-FS assumes that the direction of interface movement is parallel to an imaginary line connecting these two well locations.

\section{Estimated Movement Rates of the Saltwater Interface}

During 2014-2018 the leading edge of the saltwater interface moved past well TPGW-7L to well ACI-MW-05-FS at an average rate of about 102 meters per year $(\mathrm{m} / \mathrm{yr})$. This estimate is based on (1) a distance of $430 \mathrm{~m}$ between these wells; (2) estimated arrival dates of December 13, 2013, January 20, 2014, and April 13, 2014, at well TPGW-7L, for the 250-, 500-, and 1,000-mg/L isochlors, respectively; and (3) estimated arrival dates of September 25, 2017, April 22, 2018, and November 18, 2018,

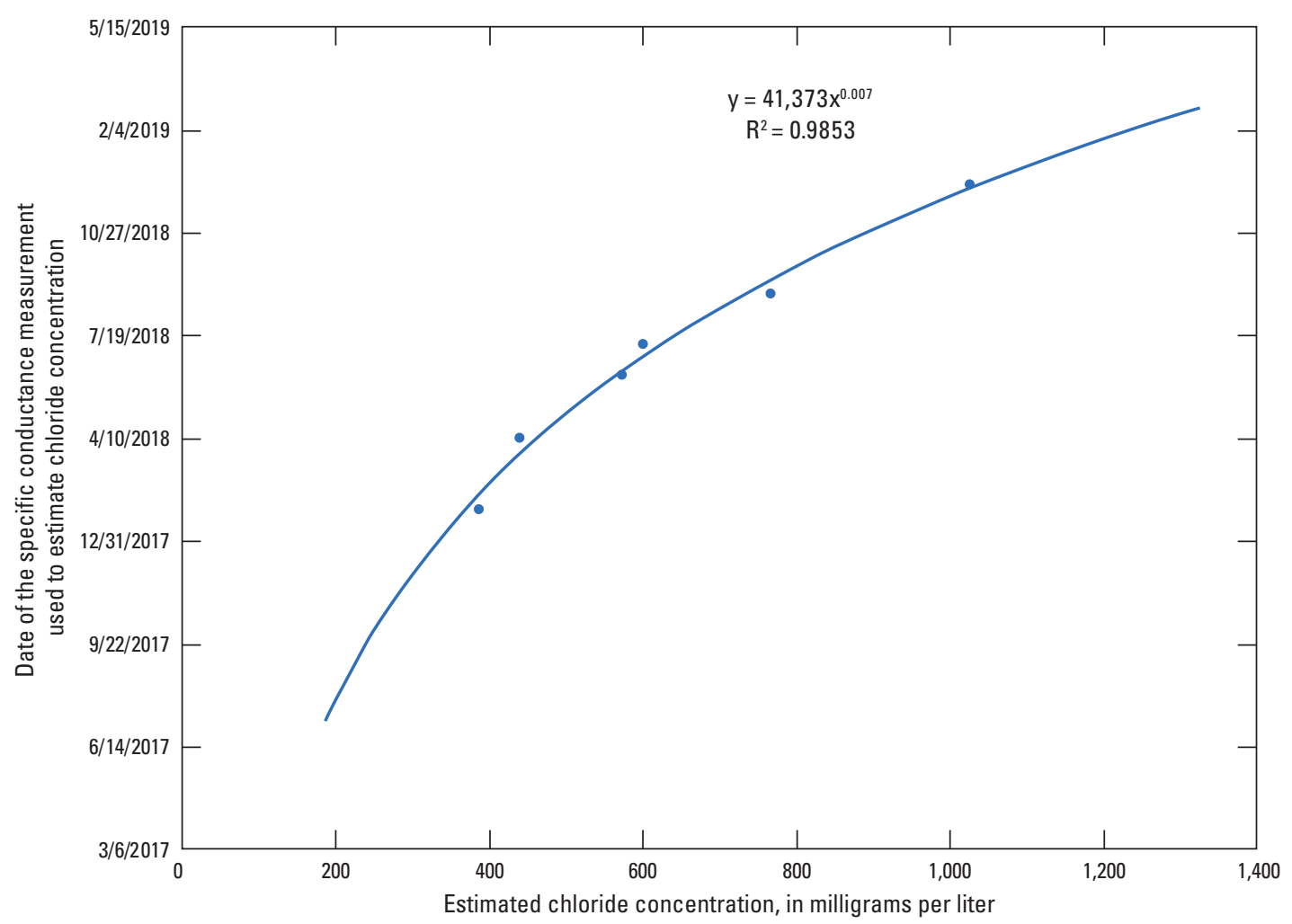

Figure 2. Regression of estimated chloride concentration in well ACI-MW-05-FS and the dates (expressed in Excel as days since January 0,1900) of the specific conductance measurements used to estimate these chloride concentrations, Miami-Dade County, Florida. 
at well ACI-MW-05-FS for these same isochlors. Given these estimates, movement rates of 114,100 , and $93 \mathrm{~m} / \mathrm{yr}$, respectively, were computed for these isochlors. These rates are less than the average rate of movement of the saltwater interface of $140 \mathrm{~m} / \mathrm{yr}$ computed by Prinos (2017b) between monitoring wells Sec34-MW-02-FS and TPGW-7L during 2007-2014. As such, the rate of movement of the interface in this part of the Model Land Area may be slowing. It took an estimated 121 days for the 250-, 500-, and 1,000-mg/L isochlors to pass well TPGW-7L (Prinos, 2017b); however, it took an estimated 419 days for these same isochlors to pass well ACI-MW-05-FS.

\section{Monitoring Network Limitations and Improvements}

The monitoring network in Miami-Dade County is likely one of the most comprehensive saltwater intrusion monitoring networks in the world when considering (1) quantity, design, and placement of monitoring wells relative to the leading edge of the saltwater interface at the base of the aquifer; (2) use of airborne and ground-based geophysical surveys and geophysical well logs to aid in mapping the interface and design of new monitoring wells; (3) availability of a web-based mapping tool to allow ongoing assessment of saltwater intrusion in the aquifer (USGS, 2019a); and (4) ongoing addition of new monitoring wells that have short screened intervals located near the base of the Biscayne aquifer. These new wells are being installed by Miami-Dade County and Florida Power \& Light Company. TSEMIL datasets are collected from these wells to ensure that changes in salinity at any depth are detected; the electromagnetic induction logging tool can detect changes in the bulk conductivity of the aquifer through the polyvinyl-chloride casing of a well. Yet, some issues can potentially affect the quality of information provided by some of the wells in this network.

One issue is that 20 of the monitoring wells in the network have open intervals longer than $4 \mathrm{~m}$ (table 3). Most of the wells that have an "FKS" prefix in their name have two to three sample tubes within an open borehole and nothing to prevent water from flowing up or down the borehole when the sample tubes are purged. All of the wells with an "ACI" prefix and "FS" suffix in their name have long screened intervals. Prinos (2013) documents numerous studies that report that flow within the well bore of long open-interval wells could bias salinity sample results. Kohout and Hoy (1963) examined data from long open-interval wells in the Biscayne aquifer. They found that if the long open interval of a well includes a freshwater-saltwater interface within it, when water is pumped from above this interface, the "...water tends to come from the upper part of the open borehole because less energy is expended by removal of low-density water from this region than by removal of high density water from the lower part of the open borehole" (Kohout and Hoy, 1963, p. 28).

Prinos and others (2014) identified vertical flow rates of 0.15-5.45 liters per minute under ambient conditions in seven out of eight open boreholes drilled in the Biscayne aquifer. Downward flow within the bore of a monitoring well could potentially obscure or eliminate the detection of saltwater intrusion at that location. Upward flow could allow saltwater entering the well bore to flow upward and intrude intervals that might not otherwise have been intruded.

Prinos and Valderrama (2015) describe that water samples for evaluation of total dissolved solids (TDS) collected from three long-screened interval wells near Lake Okeechobee yielded results that were generally too variable to identify any changes in the position of the saltwater interface. In each of the three wells, six TDS-depth profiles were collected between April 2012 and January 2013. Samples were collected at depths of every $9.1 \mathrm{~m}$, using 1-m-long straddle packers to isolate each sampling interval. The packers may have prevented upward or downward flow in the well bore during sampling but did not permanently prevent flow within the well bore during the periods between sampling events. TDS sample results varied by as much as $20-85$ percent of the maximum TDS at a given depth. They found that the "variations were much greater than those indicated by chloride concentration sampling and electromagnetic-induction logging in collocated short-screened monitoring-well clusters" (p. 23) and that the "saltwater interface evident in samples and TSEMIL datasets from..." one short screened well cluster "could not be identified in the information collected from the collocated [long-screened] well..." (p. 23). They determined that this "failure may have been caused by downward flow of freshwater from above the saltwater interface in the well bore" (p. 1).

Although some organizations are following FDEP sampling guidelines, Prinos (2013) describes that using these guidelines to collect samples from wells with long open intervals could result in samples that are not fully representative of the salinity of water in the aquifer. The FDEP guidelines were updated in 2017; however, the guidelines relating to sampling long open interval wells remained the same. Given these considerations, the saltwater intrusion monitoring network could be improved by replacing long open-interval wells ( $>4 \mathrm{~m}$ ) with short open-interval wells or at least ensuring that all new monitoring wells are of the short intake design being used by Miami-Dade County.

The analysis of the rate of movement of the saltwater interface between monitoring wells TPGW-7L and ACI-MW-05-FS required estimations of the relation between specific conductance and chloride and the relation between pumped water samples and in situ measurements of specific conductance. Estimations like these can increase uncertainty. A specific conductance measurement within a monitoring well, for example, only measures water in contact with the probe, whereas a water sample draws in water from around the well. These results might be different because it is commonly observed that the specific conductance of purge water varies to some extent during the purging process. Using a relation between specific conductance and chloride to estimate chloride concentration increases uncertainty because the relation is established by using samples from many other wells, which might yield samples that differ in water chemistry. Because of these issues, consistent sampling methodology could improve 
Table 3. Saltwater intrusion monitoring wells that have open intervals longer than 4 meters in Miami-Dade County, Florida.

[FKAA, Florida Keys Aqueduct Authority; FPL, Florida Power \& Light Company; m, meters; NA, not available; SFWMD, South Florida Water Management District; USGS, U.S. Geological Survey. USGS site identifiers, which can be used to access data stored in the USGS National Water Information System, are not available for all wells because data collected by other organizations are often not stored in the USGS database]

\begin{tabular}{|c|c|c|c|c|c|c|c|c|}
\hline Well name & $\begin{array}{l}\text { Organization } \\
\text { providing the } \\
\text { data }\end{array}$ & $\begin{array}{l}\text { USGS site } \\
\text { identifier }\end{array}$ & $\begin{array}{c}\text { Latitude } \\
\text { (decimal } \\
\text { degrees, } \\
\text { north) }\end{array}$ & $\begin{array}{c}\text { Longitude } \\
\text { (decimal } \\
\text { degrees, } \\
\text { west) }\end{array}$ & $\begin{array}{l}\text { Well } \\
\text { depth } \\
\text { (m) }\end{array}$ & $\begin{array}{l}\text { Open } \\
\text { interval of } \\
\text { well } \\
\text { (m) }\end{array}$ & $\begin{array}{l}\text { Length of } \\
\text { open } \\
\text { interval } \\
\text { (m) }\end{array}$ & $\begin{array}{c}\text { Type of well } \\
\text { opening }\end{array}$ \\
\hline ACI-MW-03-FS & $\begin{array}{l}\text { MacVicar } \\
\text { Consulting }\end{array}$ & NA & 25.419 & -80.442 & 30.5 & $6.1-30.5$ & 24.4 & Long screen \\
\hline ACI-MW-04-FS & $\begin{array}{l}\text { MacVicar } \\
\text { Consulting }\end{array}$ & NA & 25.426 & -80.436 & 30.5 & $6.1-30.5$ & 24.4 & Long screen \\
\hline ACI-MW-05-FS & $\begin{array}{l}\text { MacVicar } \\
\text { Consulting }\end{array}$ & NA & 25.435 & -80.432 & 30.5 & $6.1-30.5$ & 24.4 & Long screen \\
\hline ACI-MW-09-FS & $\begin{array}{l}\text { MacVicar } \\
\text { Consulting }\end{array}$ & NA & 25.419 & -80.452 & 45.7 & $6.1-45.7$ & 39.6 & Long screen \\
\hline F - 279 & USGS & 255315080111501 & 25.888 & -80.187 & 35.7 & $0.0-35.7$ & 35.7 & Open holed \\
\hline FKS 1 & FKAA & 251949080313101 & 25.330 & -80.526 & 13.7 & $6.1-13.7$ & 7.6 & Open hole \\
\hline FKS 2 & FKAA & 251953080293301 & 25.331 & -80.493 & 13.7 & $4.6-13.7$ & 9.1 & Open hole \\
\hline FKS 5 & FKAA & 252228080293501 & 25.375 & -80.493 & 18.3 & $9.1-18.3$ & 9.1 & Open hole \\
\hline FKS 6 & FKAA & 252143080313001 & 25.362 & -80.525 & 21.3 & $9.1-21.3$ & 12.2 & Open hole \\
\hline FKS 7 & FKAA & 252228080275701 & 25.375 & -80.466 & 18 & $8.8-18.0$ & 9.1 & Open hole \\
\hline FKS 8 & FKAA & 252347080265701 & 25.397 & -80.449 & 24.1 & $9.1-24.1$ & 14.9 & Open hole \\
\hline FKS 10 & FKAA & NA & 25.432 & -80.474 & 24.4 & $9.1-24.4$ & 15.2 & Open hole \\
\hline FKS 11 & FKAA & NA & 25.411 & -80.471 & 18.3 & $9.1-18.3$ & 9.1 & Open hole \\
\hline FKS 12 & FKAA & NA & 25.392 & -80.467 & 21.9 & $9.1-21.9$ & 12.8 & Open hole \\
\hline FKS 13 & FKAA & NA & 25.349 & -80.493 & 19.8 & $9.1-19.8$ & 10.7 & Open hole \\
\hline FKS 14 & FKAA & NA & 25.419 & -80.436 & 25.9 & $9.1-25.9$ & 16.8 & Open hole \\
\hline FKS 15 & FKAA & NA & 25.448 & -80.460 & 25.9 & $9.1-25.9$ & 16.8 & Open hole \\
\hline G-896 & USGS & 254107080165201 & 25.686 & -80.281 & 22.6 & $18.3-22.6$ & 4.3 & Open holed \\
\hline G-1180 & USGS & 252947080235301 & 25.498 & -80.404 & 20.4 & $0.0-20.4$ & 20.4 & Open holed \\
\hline G-3313E & USGS & 253831080180206 & 25.643 & -80.301 & 34.7 & $9.8-34.7$ & 25 & Open holed \\
\hline
\end{tabular}

the quality of the network and the accuracy of estimates of interface movement rates.

Addition of new wells where needed can decrease uncertainty in the location of the saltwater interface. Elimination of monitoring that is no longer needed could reduce the resources needed to maintain the network. A list of locations where monitoring wells could be added to improve understanding of the inland extent of saltwater intrusion in the Biscayne aquifer and to determine its rate of movement is provided in table 4 . The reasons for the proposed additions are also provided in table 4 . As the leading edge of the interface passes wells and its location is tightly constrained by other wells, then monitoring at the wells that the interface passed can be discontinued, unless future actions are expected to reverse the extent of intrusion. Salinity monitoring could potentially be discontinued at wells F-279, G-894, and G-3699 for this reason. Well G-3224 is shallow and could be discontinued if replaced by a deeper well. Well G-1180 is too shallow and has a long open interval; this well also could potentially be discontinued if replaced. The leading edge of the saltwater interface may soon pass monitoring wells G-3603 and G-3996 and the well cluster G-3977; salinity monitoring at the locations of wells F-45, G-3605, G-3609, and G-3704 and the well cluster G-3888 would then no longer be necessary. The saltwater interface is currently located to the east of wells G-1351 and G-1354 and to the west of well G-3064. Water samples from wells G-354 and G-548, located farther inland than G-1354, show that chloride concentration has been decreasing for almost 40 years (USGS, 2019b). The frequency of salinity monitoring at these wells could potentially be reduced until the saltwater interface passes wells G-1351 or G-1354. Well G-3250 is located farther inland along the Miami Canal. Chloride concentrations in water samples from this well have been below $250 \mathrm{mg} / \mathrm{L}$ for the last 6 years (USGS, 2019b). Frequency of this monitoring also could potentially be reduced. Continuous salinity monitoring in the Miami Canal could indicate if increased groundwater salinity monitoring is needed in this area. Resumption of induction logging at well G-3610 could aid in the mapping of the inland extent of saltwater intrusion. 
Table 4. Proposed locations and reasons for new monitoring wells in Miami-Dade County, Florida.

[km, kilometers; m, meters; N, north; NNE, north-northeast; NNW, north-northwest; NW, northwest; S, south; SSW, south-southwest; SW, southwest; W, west; WNW, west-northwest; WSW, west-southwest; NS, not specified; SFWMD, South Florida Water Management District; SWIM, saltwater intrusion monitoring; USGS, U.S. Geological Survey]

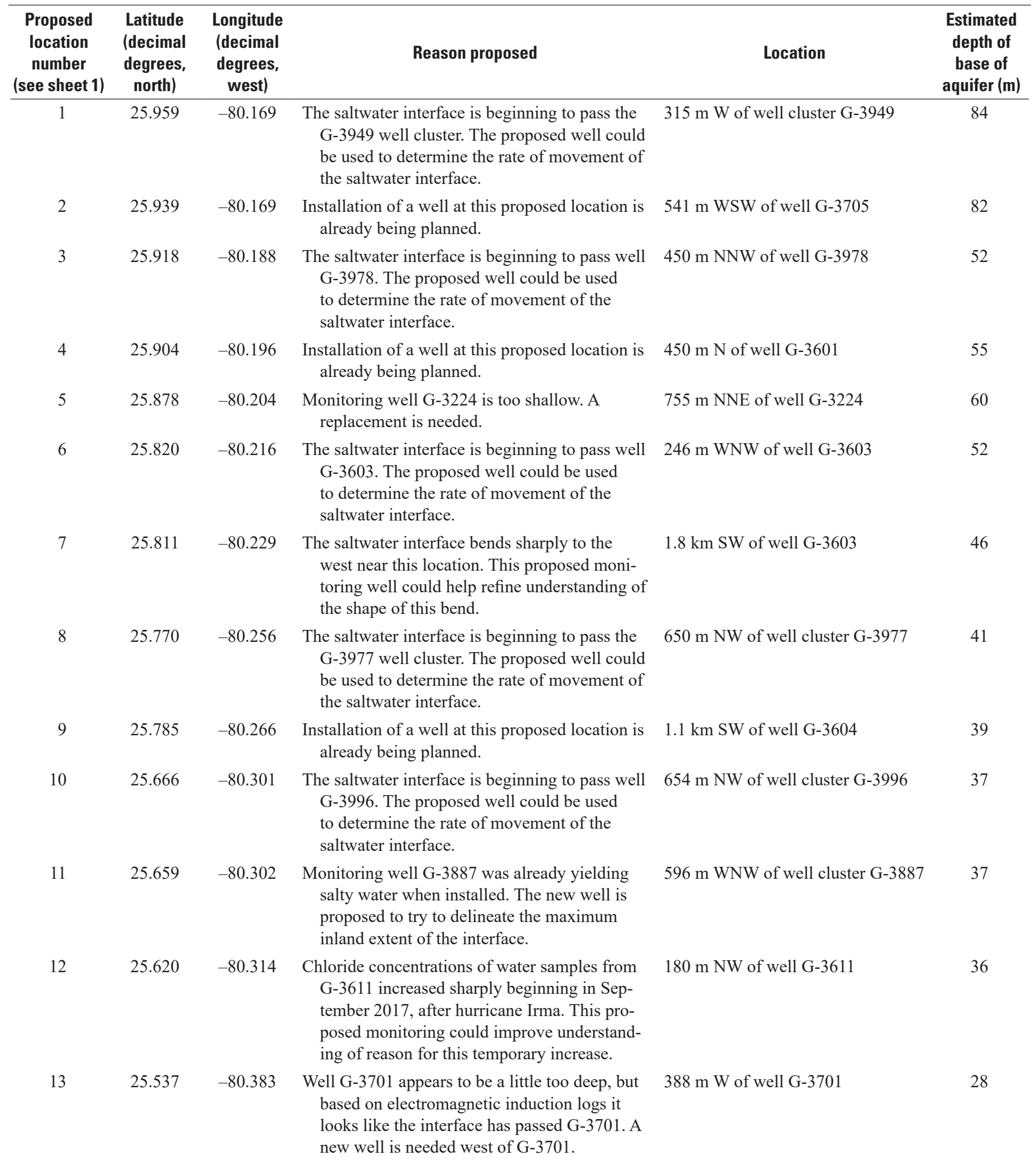


Table 4. Proposed locations and reasons for new monitoring wells in Miami-Dade County, Florida.—Continued

[km, kilometers; m, meters; N, north; NNE, north-northeast; NNW, north-northwest; NW, northwest; S, south; SSW, south-southwest; SW, southwest; W, west; WNW, west-northwest; WSW, west-southwest; NS, not specified; SFWMD, South Florida Water Management District; SWIM, saltwater intrusion monitoring; USGS, U.S. Geological Survey]

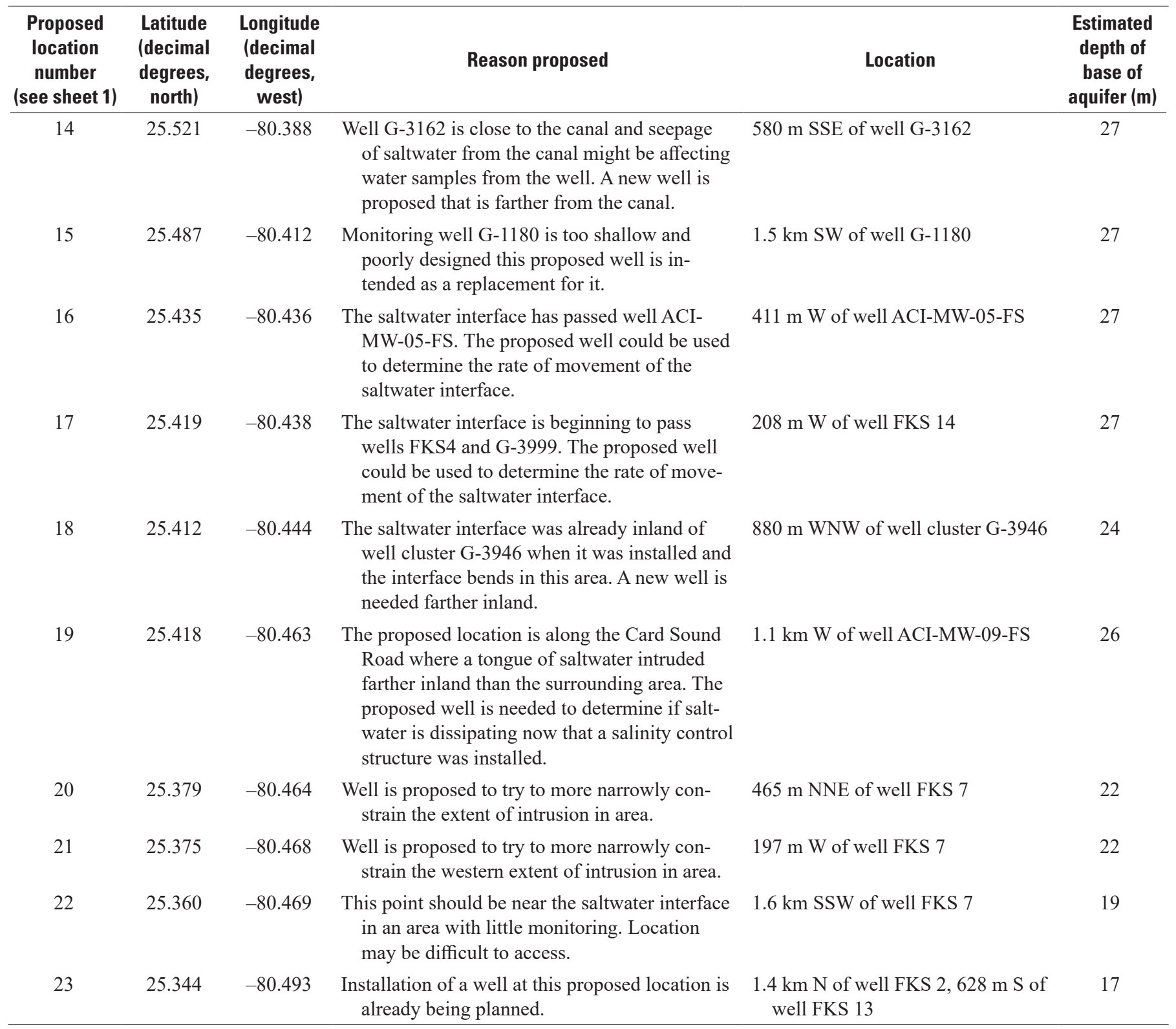




\section{References Cited}

Fish, J.E., and Stewart, Mark, 1991, Hydrogeology of the surficial aquifer system, Dade County, Florida: U.S. Geological Survey Water-Resources Investigations Report 90-4108, 50 p., 11 sheets.

Fletcher, D.U., 1911, Everglades of Florida: Acts, reports and other papers State and National, relating to the Everglades of the State of Florida and their reclamation: Washington, Government Printing Office, 193 p.

Florida Department of Environmental Protection [FDEP], 2017, Groundwater sampling: Florida Department of Environmental Protection, Standard Operating Procedures, DEP-SOP-001/01 FS 2200, 26 p., app., accessed February 26, 2019, at https://floridadep.gov/dear/qualityassurance/content/dep-sops.

Florida Power \& Light Company, 2011, Quality Assurance Project Plan — Turkey Point Monitoring Project: Florida Power \& Light Company, 170 p., 9 app., accessed February 22, 2017, at https://www.sfwmd.gov/documentsby-tag/fpltpsurvey?sort_by=title\&sort_order=DESC.

Kohout, F.A., and Hoy, N.D., 1963, Some aspects of sampling salty ground water in coastal aquifers: Ground Water, v. 1, no. 1, p. $28-32$.

Prinos, S.T., 2013, Saltwater intrusion in the surficial aquifer system of the Big Cypress Basin, southwest Florida, and a proposed plan for improved salinity monitoring: U.S. Geological Survey Open-File Report 2013-1088, 58 p., accessed January 5, 2017, at https://pubs.usgs.gov/ of/2013/1088/.

Prinos, S.T., 2017a, Data pertaining to mapping the approximate inland extent of saltwater at the base of the Biscayne aquifer in the Model Land Area of Miami-Dade County, Florida, 2016: U.S. Geological Survey data release, accessed January 5, 2017, at https://doi.org/10.5066/ F7R78CF8.

Prinos, S.T., 2017b, Map of the approximate inland extent of saltwater at the base of the Biscayne aquifer in the Model Land Area of Miami-Dade County, Florida, 2016: U.S. Geological Survey Scientific Investigations Map 3380, 8-p. pamphlet, 1 sheet, accessed January 5, 2017, at https://doi.org/10.3133/sim3380.
Prinos, S.T., 2019, Data pertaining to mapping the approximate inland extent of saltwater at the base of the Biscayne aquifer in Miami-Dade County, Florida, 2018: U.S. Geological Survey data release, https://doi.org/10.5066/P9ZIC1O4.

Prinos, S.T., and Valderrama, Robert, 2015, Changes in the saltwater interface corresponding to the installation of a seepage barrier near Lake Okeechobee, Florida: U.S. Geological Survey Open-File Report 2014-1256, 24 p., accessed January 5, 2017, at https://pubs.usgs.gov/ of $/ 2014 / 1256 /$.

Prinos, S.T., Wacker, M.A., Cunningham, K.J., and Fitterman, D.V., 2014, Origins and delineation of saltwater intrusion in the Biscayne aquifer and changes in the distribution of saltwater in Miami-Dade County, Florida: U.S. Geological Survey Scientific Investigations Report 2014-5025, 101 p., accessed January 5, 2017, at http://dx.doi.org/10.3133/ $\operatorname{sir} 20145025$.

U.S. Census Bureau, 2019, QuickFacts, Miami-Dade County, Florida: U.S. Census Bureau QuickFacts website, accessed May 3, 2019, at https://www.census.gov/quickfacts/fact/ table/miamidadecountyflorida/POP060210.

U.S. Environmental Protection Agency, 2017, Secondary drinking water standards: Guidance for nuisance chemicals: U.S. Environmental Protection Agency, accessed February 22, 2019, at http://water.epa.gov/drink/ contaminants/secondarystandards.cfm.

U.S. Geological Survey [USGS], 2019a, Water Level and Salinity Analysis Mapper: U.S. Geological Survey website, accessed February 22, 2019, at https://fl.water.usgs.gov/mapper/.

U.S. Geological Survey [USGS], 2019b, USGS water data for the Nation: U.S. Geological Survey National Water Information System database, accessed February 22, 2019, at https://doi.org/10.5066/F7P55KJN.

U.S. Geological Survey [USGS], variously dated, National field manual for the collection of water-quality data: U.S. Geological Survey Techniques of Water-Resources Investigations, book 9, chaps. A1-A9, available online at http://pubs.water.usgs.gov/twri9A.

Valderrama, R., 2018, Time Series Electromagnetic InductionLog Datasets, Including Logs Collected through the 2017 Water Year in South Florida: U.S. Geological Survey data release, https://doi.org/10.5066/F70R9NPF. 
For more information about this publication, contact

Director, Caribbean-Florida Water Science Center

U.S. Geological Survey

4446 Pet Lane, Suite 108

Lutz, FL 33559

(813) 498-5000

For additional information visit

https://www2.usgs.gov/water/caribbeanflorida/index.html

Publishing support provided by

Lafayette Publishing Service Center 
